\title{
A comparison of sustainability objectives: how well does the Canadian Fisheries Research Network framework compare with fisheries, forestry, and aquaculture certification schemes?
}

\author{
Claire Mussells $^{1,2}$ and Robert L. Stephenson ${ }^{1,3}$
}

\begin{abstract}
It is increasingly recognized that fisheries management should take a more holistic approach toward full spectrum sustainability that includes ecological, social, and economic considerations. The Canadian Fisheries Research Network (CFRN) has developed an evaluation framework for comprehensive fisheries management, derived from Canadian policy and international commitments. In the changing landscape of resource management, third party market certification has grown where there are perceived management gaps and increasingly exerts pressure on management considerations. Increasingly, there is a need to integrate coastal management and to consider consistent management objectives across sectors. In this study, the CFRN framework is used as a lens with which to compare certification schemes (fisheries, aquaculture, and forestry) of relevance to activities in southwest New Brunswick. This analysis reveals (1) that the three certification schemes differ in the scope of their objectives; (2) that a number of CFRN framework elements are not addressed in the certification schemes; and (3) that the certification scheme that most closely matches the CFRN framework is from the forestry sector and that the Marine Stewardship Council certifications scheme for fisheries is most different from the CFRN because it lacks consideration of social and economic aspects. We are thus challenged to consider why fisheries management and certification continue to fall behind in the consideration of a broad spectrum of management objectives and we are provided with an opportunity to learn from the strengths of other sectors.
\end{abstract}

Key Words: ecosystem-based management; management objectives; social-ecological systems; sustainable development; third party market certification

\section{INTRODUCTION}

The management of Canada's oceans and its resources has evolved in the past decades and continues to change, as has been the case internationally. Whereas the traditional management system focused on the management of single sectors or activities with a narrow set of objectives, it is increasingly recognized that coastal management should take a more holistic approach. Canada's Sustainable Development Act and Oceans Act both support the movement toward an ecosystem-based approach to management (GC DOJ 1996, 2008). Our understanding of the ecosystems and the important services that they provide continues to grow, and there is increased appreciation within an ecosystembased management approach of the social and economic benefits that ecosystems provide (Long et al. 2015). Today's management is shifting toward one that recognizes a broader set of ecological objectives (Pikitch et al. 2004), as well as economic, social, and institutional goals of social-ecological systems (Stephenson et al. 2017). Effective coastal management requires further articulation and use of a comprehensive set of objectives, and consistency in core objectives across all activities in an area (e.g., Stephenson et al. 2019a).

In the early 1990s, environmental groups, frustrated with the lack of progress by international governments to reduce environmental impacts, called for the development of third party market certifications (Bush et al. 2013). Certification developed in a number of sectors in which there were perceived management or regulatory gaps including organic farming, tourism, and harvested resources. Certifications, through the use of standards, essentially impose objectives on activities. The movement has gained strength as public awareness of environmental and social issues has grown and consumers increasingly are interested in where and how products are harvested, produced, and manufactured. The expectation was that certification would result in a market advantage for certified producers because certification offers a mechanism for consumers interested in making sustainable and socially responsible choices (Rametsteiner and Simula 2003). In turn, certification is exerting pressure through markets and economic incentives toward a shift in management considerations. Market driven governance is a topic that has been explored extensively in the literature including its role in changing global practices, increasing corporate social responsibility, and the relative merits of different schemes (Cashore 2002, Rametsteiner and Simula 2003, Clark and Kozar 2011, Kalfagianni and Pattberg 2013). Our study arose from interest in the scope of certification schemes in relation to evolving coastal management.

\section{Full spectrum sustainability has four pillars}

Sustainability of social-ecological systems has been recognized as broad and to include both natural and human dimensions. The Canadian Fisheries Research Network (CFRN), a research collaboration among Canadian industry, academia, and government (Thompson et al. 2019), developed a framework for comprehensive evaluation of sustainability (Stephenson et al. $2018,2019 b$ ). The framework identified the spectrum of candidate fisheries management objectives and potential performance indicators within the four domains, or pillars of sustainability: ecological, economic, social (including cultural), and institutional. The elements that form this framework were derived

${ }^{1}$ Canadian Fisheries Research Network, Fisheries and Oceans Canada, St Andrews Biological Station, St Andrews, New Brunswick, ${ }^{2}$ Faculty of Forestry and Environmental Management, University of New Brunswick, ${ }^{3}$ Canadian Fisheries Research Network, Department of Biology, University of New Brunswick 
from Canada's laws and acts as well as from international commitments in relation to sustainable fisheries (Stephenson et al. 2019b).

The CFRN framework was developed with the goal of providing a tool or report card to comprehensively assess the management of fisheries, to determine the shortcomings of management, and to identify where management fails to meet policy commitments. The framework was compared with other proposed frameworks internationally and is comprehensive in relation to the sustainability of coastal social-ecological systems (Stephenson et al.2018). In the context of a shift toward a more holistic ecosystem approach to management and the recognition of the need for the management of diverse activities for a similar range of objectives, this framework can be applied beyond fisheries. The purpose of this study was to compare the scope of the CFRN full-spectrum sustainability framework with that of certification schemes.

There has been considerable effort to evaluate the merits and effectiveness of individual certification schemes (Tikina and Innes 2008, Parkes et al 2010, Clark and Kozar 2011, Jonell et al. 2013, Kalfagianni and Pattberg 2013). In contrast, there has been limited work to compare certification schemes across sectors. There has been some comparison of differences in institutional and governance structures of certification schemes (e.g., Gale and Haward 2004, Gulbrandsen 2005). Some work has also been done across sectors to determine what qualities of a certification scheme are most effective at implementing sustainable development objectives such as quality of the audit, stringency of standards, and degree of uptake (Schlyter et al. 2009, Kalfagianni and Pattberg 2013) . Market certification is not without its criticisms and there exists a large body of research on the shortcomings of certification including a lack of standard stringency, leniency by third party auditors, exclusion of artisanal and developing world fishers, and failure to make meaningful change to management practices (Jacquet and Pauly 2007). It should be noted that the intent of this analysis is not to compare the merits of particular schemes or the effectiveness of third-party certification but rather to evaluate the extent to which the objectives reflect full-spectrum sustainability and how consistently those objectives are applied across sectors. We hypothesized that certification schemes, which are aimed at improving sustainability would be similar in scope, and that they should reflect the full-spectrum sustainability articulated in the CFRN framework.

\section{METHODS}

We used the CFRN framework as a lens to compare three certification schemes of relevance to activities in the southwest New Brunswick/Bay of Fundy region. We were interested in comparing the objectives of certifications within the same geographic area. The Bay of Fundy, in particular the southwest New Brunswick region was chosen as a case study because the area has a number of important resource-based activities, and there has been interest in integrated management of diverse activities in the area. Three resource-based activities were chosen: fisheries, aquaculture, and forestry. These activities have been recently influenced by certification schemes internationally (e.g., Rametsteiner and Simula 2003, Jacquet and Pauly 2007, Bush et al. 2013) and are important activities in the study region.
A number of fisheries have had a long history and are still very active in southwest New Brunswick including lobster, scallops, and herring. Within the Bay of Fundy, salmon aquaculture has become a prominent economic driver in the last 30 years. The aquaculture industry shares the same space as fisheries and the interaction between these two activities means that it is important that they have complimentary management objectives. Forestry was chosen as an activity to study because it is an adjacent terrestrial resource harvesting activity that increasingly needs to be considered in a regional (watershed) integrated management setting.

The study focused on the management pressures and activities in and around the Bay of Fundy, therefore certification standards were chosen that are relevant to the Bay of Fundy. For fisheries we chose the Marine Stewardship Council (MSC). This is a prevalent fisheries certification scheme that has been used to certify the Bay of Fundy scallops since 2013 (MSC 2019a), lobster (since 2015; MSC 2019b), and herring purse seine fisheries (2016-2019; MSC 2019c). The MSC standard does not vary spatially or by species so the universal criteria were used in this analysis (MSC 2014).

At the time of this research, there was recognition that certification of aquaculture products with respect to sustainability was becoming an important market driver, but there was no single dominant certification scheme (GNB 2010). The Aquaculture Stewardship Council(ASC) certification is prevalent internationally and has a similar origin to that of MSC. Aquaculture standards differ by species in production. Salmon aquaculture constitutes the majority of aquaculture within the Bay of Fundy, therefore the ASC salmon standard (ASC 2012) was chosen for this analysis.

The Province of New Brunswick requires that all Crown forest lands managed by timber licensees are certified by one of three third-party forest certification systems (GNB 2014). We chose to focus on the Forestry Stewardship Council (FSC) because in meta-analyses, the FSC is shown to be superior in scope and more prescriptive where specific benchmarks must be met (Gulbrandsen 2009, Clark and Kozar 2011). The FSC develops standards for different geographical regions, recognizing differences in ecological and socioeconomic environments. The Certification Standards for Best Forestry Practices in the Maritimes Region was chosen for this analysis (FSC 2008).

For each certification scheme, the evaluation criteria in the standards were analyzed and each requirement was matched as closely as possible to the most relevant element in the CFRN framework (see Appendix 1). This was a somewhat subjective process but focused on matching each requirement of the certification criteria to CFRN framework keywords (Table 1) and assigning each requirement to the appropriate CFRN objective. In a few cases, one certification criterion covered two CFRN elements and thus was included in both.

The schemes were then classified as treating each element "completely," "partially," or "not at all." A classification of "complete" certainly does not imply that the scheme has a perfect treatment of the framework element, but that it was a wellrounded treatment of the element or captures the spirit of that 
Table 1. Canadian Fisheries Research Network (CFRN) fisheries sustainability framework detailed objectives and keywords (as presented in Stephenson et al. 2019b).

\begin{tabular}{|c|c|c|}
\hline & Element & Objective Description/Keywords \\
\hline \multirow[t]{3}{*}{ Ecological } & Productivity & Productivity, trophic structure \\
\hline & Biodiversity & Within population, food web persistence, community-level, nonnative species \\
\hline & Habitat & Ecosystem integrity (physical and chemical), substrate, and ecosystem services \\
\hline \multirow[t]{3}{*}{ Institutional } & Obligations to laws & Legal obligations including to indigenous peoples \\
\hline & Good governance structure & $\begin{array}{l}\text { Collaboration, shared stewardship, participation, roles and responsibilities of } \\
\text { participants, policies, agreements }\end{array}$ \\
\hline & Effective decision-making process & $\begin{array}{l}\text { Democratic, participatory, transparent, openly communicated, integrated, } \\
\text { structured, collaborative, cooperative, responsible and effective management, } \\
\text { compliance, accountability, adaptive management }\end{array}$ \\
\hline \multirow{6}{*}{$\begin{array}{l}\text { Social and } \\
\text { Economic }\end{array}$} & Sustainable communities & Community well-being, social capital, informed citizenry, heritage \\
\hline & Health and well-being & Occupational safety, food security \\
\hline & Ethical fisheries & Equity, rights \\
\hline & Economic/financial viability & Sustainable livelihoods, sustainable wealth, prosperity \\
\hline & Distribution of access and benefits & $\begin{array}{l}\text { Distributed benefits: equity, fairness, allocation, equitable trading } \\
\text { relationships, intergenerational equity }\end{array}$ \\
\hline & Regional economic benefits to community & Creation of synergies through integration of regional community resources \\
\hline
\end{tabular}

element. The classification of "partially" complete was assigned when there was some treatment of the element by the certification criteria but did not capture all facets of the element. For example, the MSC certification was assigned a partially complete treatment of the CFRN biodiversity element. The MSC criteria 2.3.2 states that the fisheries must "...not hinder the recovery of ETP [endangered, threatened, or protected] species," which serves to protect biodiversity but never specifies biodiversity as a concern and only deals with one level of diversity (species; MSC 2014).

\section{RESULTS}

\section{Ecological aspects}

The certification schemes cover a similar breadth of ecological criteria summarized in Figure 1 (details in Appendix 1). All three certification schemes include the three ecological elements identified by the CRFN framework: productivity, biodiversity, and habitat. The FSC criteria cover the ecological integrity of the entire ecosystem and appear to be the most comprehensive treatment of ecological issues of the certification schemes. The maintenance of productivity of forest products is addressed by requiring that ecological function be "maintained intact, enhanced and restored" through the natural cycles of regeneration and succession (FSC 2008). The FSC also protects the productivity of the forest by preventing forest conversion to plantation or nonforested land and ensures that biodiversity is maintained at every level; genetic through landscape diversity. It specifies that the forest management plan will protect genetic, species, and ecosystem diversity by protecting endangered species and their habitats and maintaining representative ecosystems within the forest landscape and preventing the conversion of forests into less genetically diverse plantations. Finally, the FSC considers the final ecological element of habitat in its certification criteria by requiring that forest management techniques be implemented to control erosion, to prevent forest and watershed damage, and to reduce the use of chemical pest management. The FSC is particularly concerned with forests that are deemed to be of high conservation value based on their species diversity, presence of rare habitats, important ecosystem services, cultural value, or community needs. The Maritimes FSC standard recognizes the region's unique mix of hardwood and softwood stands and the abundance of red spruce, which characterizes the Acadian forest. This FSC standard also recognizes the history of use of forest resources by indigenous peoples.

Fig. 1. Certification criteria of three certification schemes categorized as complete (green), partial (yellow), or no (white) treatment of ecological elements of the Canadian Fisheries Research Network (CFRN) sustainability framework evaluation criteria.

\begin{tabular}{|c|c|c|c|}
\hline $\begin{array}{c}\text { CFRN Framework } \\
\text { Element }\end{array}$ & $\begin{array}{c}\text { Forest } \\
\text { Stewardship } \\
\text { Council }\end{array}$ & $\begin{array}{c}\text { Aquaculture } \\
\text { Stewardship } \\
\text { Council }\end{array}$ & $\begin{array}{c}\text { Marine } \\
\text { Stewardship } \\
\text { Council }\end{array}$ \\
\hline $\begin{array}{c}\text { Productivity and } \\
\text { trophic structure }\end{array}$ & & & \\
\hline Biodiversity & & & \\
\hline $\begin{array}{c}\text { Habitat and } \\
\text { ecosystem integrity }\end{array}$ & & & \\
\hline
\end{tabular}

The ASC's second principle: to "conserve natural habitat, local biodiversity and ecosystem function" outlines the ASC's position on ecological criteria in its aquaculture certification. Because the productivity of resources, such as a fish species or forest product, is not within the scope of an aquaculture company's concern, the ASC criteria on ecological productivity are aimed at preventing aquaculture operations from affecting the ecosystem functions. This includes predator interactions, amplified parasites due to salmon cages, and the introduction of non-native species. Because many aquaculture operations use wild fish as feed, the ASC requires that companies demonstrate that wild feed comes from environmentally responsible sources (Bush et al. 2013). The ASC 
considers biodiversity in its certification and it will not certify an operation that uses transgenic species because of concerns of the impact they may have on a wild population. The ASC also limits the release of escaped salmon. The ASC considers the final CFRN ecological element, habitat, by requiring the demonstration of good water quality and limited nutrient release surrounding the salmon cage site.

The MSC addresses the CFRN framework ecological criteria in standards laid out by two of the three guiding principles of the MSC standard: (1) sustainable target fish stocks, and (2) environmental impact of fishing (MSC 2014). The certification standards are primarily concerned with maintaining the productivity levels of the primary, or harvested stock, as well as preventing irreversible harm to key elements of the ecosystem structure. The MSC addresses biodiversity in its requirements to ensure that the harvest of the target species does not hinder the recovery of endangered, threatened, or protected species but never outright specifies biodiversity as a concern, thus leading to its classification as partial treatment of biodiversity objectives. Finally, the MSC has standards to protect marine habitat by requiring that a strategy exists to ensure that the harvest does not cause risk of irreversible harm to habitat.

\section{Institutional aspects}

The three certification schemes that were analyzed each had standard requirements that recognized existing formal and informal institutional arrangements in the management of the resource (Fig. 2; see Appendix 1 for details). Each certification scheme requires that the forestry operation, aquaculture production, or fishery comply with existing legislation in which the operation exists.

Fig. 2. Certification criteria of three certification schemes categorized as complete (green), partial (yellow), or no (white) treatment of institutional elements of the Canadian Fisheries Research Network (CFRN) sustainability framework evaluation criteria.

\begin{tabular}{|c|c|c|c|}
\hline $\begin{array}{c}\text { CFRN Framework } \\
\text { Element }\end{array}$ & $\begin{array}{c}\text { Forest } \\
\text { Stewardship } \\
\text { Council }\end{array}$ & $\begin{array}{c}\text { Aquaculture } \\
\text { Stewardship } \\
\text { Council }\end{array}$ & $\begin{array}{c}\text { Marine } \\
\text { Stewardship } \\
\text { Council }\end{array}$ \\
\hline $\begin{array}{c}\text { Obligations to laws } \\
\text { and indigenous } \\
\text { peoples }\end{array}$ & & & \\
\hline $\begin{array}{c}\text { Good governance } \\
\text { structure }\end{array}$ & & & \\
\hline $\begin{array}{c}\text { Effective decision- } \\
\text { making processes }\end{array}$ & & & \\
\hline
\end{tabular}

Additionally, the certification schemes require that informal institutional agreements be recognized in the management of the resource. All three have provisions that operations must recognize the right of those dependent on the resource or having customary rights to land. In the MSC scheme, there is only one mention of social issues surrounding the use of the resource: the MSC requires a framework for cooperation and a mechanism for resolution of disputes between the unit of assessment, i.e., the stock, method/gear, and eligible fishers, and the people dependent on the resource for their livelihood. The FSC and ASC explicitly consider the rights of indigenous people to their traditional land. The ASC standard requires evidence of consultation with indigenous peoples whereas the FSC standard goes a step further and requires that operations show evidence for indigenous peoples' long-term rights to the land in reference to customary rights to land and maintains that management shall not reduce the access/tenure of indigenous people. Thus, MSC and ASC recognize the right of traditional users and require consultation whereas FSC assumes that the rights to the land belong to traditional users/indigenous peoples unless proven otherwise.

Each certification scheme acknowledges that consultation is an important aspect of resource management. Participatory and transparent management is also outlined in the CFRN framework criteria for decision making. Effective consultation with interested parties is required by the MSC and the ASC for certification. The FSC similarly requires ongoing consultation with affected parties but stipulates that both men and women must be consulted.

The FSC and the MSC share other similarities in their approach to decision-making standardization. They both have a number of requirements for ensuring that adequate information exists to make decisions. The MSC certification is particularly concerned with determining risk to populations and habitat, which reflects the more ambiguous nature of managing a marine resource rather than a terrestrial one. Forestry does not generally consider risk of overharvesting because there is better knowledge of stock levels. The FSC does have requirements for the frequency of monitoring and what indicators of forest health need to be collected. The FSC also requires that forest management plans are frequently updated to reflect new information from monitoring as well as changing environmental, social, and economic circumstances. The ASC certification standard contains no requirements for data collection, monitoring, or data quality for decision making, although monitoring is required by the ASC chain of custody standards.

\section{Socioeconomic aspects}

There are major differences in the scope of the social and economic considerations in the three certification schemes. The most notable difference is that the MSC certification scheme has little consideration of social or economic management objectives (Fig. 3; details in Appendix 1). The MSC certification requires that the fishery does not hinder the use of the resource by people dependent on it and requires that there be consultation during management decision making, but that is the extent of social and economic considerations. The CFRN framework lays out a full suite of social and economic objectives for management including building sustainable communities, the health and well-being of workers and people.

Both the FSC and ASC certification schemes address many of these social and economic management objectives. The FSC standard addresses each of the socioeconomic management concerns laid out in the CFRN framework including that of sustainable communities. The FSC standard requires that the forestry operation considers the effect the activity will have on surrounding communities including evaluations of social impact. The FSC also requires that these communities directly benefit from the forest operation through the employment and training 
of local people. Thus the economic benefits of the forestry operation should flow to nearby communities. Communities and people benefit not just from the economic value that can be derived from forests but also through the ecological services that they provide. The FSC standard recognizes the significance of ecological services to human health and community sustainability and requires that forest operations "maintain, and where appropriate, enhance" ecological services (FSC 2008).

Fig. 3. Certification criteria of three certification schemes categorized as complete (green), partial (yellow), or no (white) treatment of social and economic elements of the Canadian Fisheries Research Network (CFRN) sustainability framework evaluation criteria.

\begin{tabular}{|c|c|c|c|}
\hline $\begin{array}{c}\text { CFRN Framework } \\
\text { Element }\end{array}$ & $\begin{array}{c}\text { Forest } \\
\text { Stewardship } \\
\text { Council }\end{array}$ & $\begin{array}{c}\text { Aquaculture } \\
\text { Stewardship } \\
\text { Council }\end{array}$ & $\begin{array}{c}\text { Marine } \\
\text { Stewardship } \\
\text { Council }\end{array}$ \\
\hline $\begin{array}{c}\text { Sustainable } \\
\text { communities } \\
\text { Health and well- } \\
\text { being }\end{array}$ & & & \\
\hline $\begin{array}{c}\text { Ethical fisheries } \\
\text { Economic/financial } \\
\text { viability }\end{array}$ & & & \\
\hline $\begin{array}{c}\text { Distribution of } \\
\text { access and benefits }\end{array}$ & & & \\
\hline $\begin{array}{c}\text { Regional economic } \\
\text { benefits to } \\
\text { community }\end{array}$ & & & \\
\hline
\end{tabular}

The FSC and ASC consider the health and safety of employees and thus address the CFRN category of health and well-being by addressing occupational health. The FSC simply requires that all applicable laws for the health and safety of workers are met. The ASC certification standard has detailed standards for worker health and safety but also for worker management practices including conflict resolution, working hours, and disciplinary action. The MSC does not require any health or safety standards to be met for certification of a fishery.

The CFRN framework outlines ethical fisheries as a management objective; this includes improving human well-being and equity as well as rights of indigenous peoples. These objectives are not addressed in the MSC certification but are addressed by the FSC and ASC as applied to their respective sectors. The FSC requires that sites of cultural, ecological, economic, or religious importance to indigenous peoples be protected. The FSC also addresses the element of equitable fisheries by requiring forest operations to allow their workers the right to collective bargaining. The ASC has a similar standard in their scheme for collective bargaining. The ASC certification scheme is also unique in this category in that it has specific requirements that prevent child labor, forced labor, or discrimination.
The FSC standards further consider the effects of the forestry operation on the community. The economic viability of an operation and of the surrounding community must be considered in the management plan for the forest. The FSC standards require that managers consider the full cost of production including ecological and social costs. This means that the forest operation must not damage other nontimber forest products or exceed a sustainable level of harvest. The FSC scheme requires that forest management should diversify local economies and not encourage dependence on a forest. Considerations of the effect of an operation on the surrounding communities' economy and actively preventing dependence while encouraging diversification for economic sustainability is unique to the FSC.

\section{DISCUSSION}

\section{Common origin of certification schemes}

Product certification developed from concerns by environmental nongovernmental organizations (NGOs) of growing global environmental degradation and their perception of a lack of sufficient government action to address these issues (Gulbrandsen 2005). Market certification was first introduced in the forestry industry in which unsustainable forestry practices led to concerns about global deforestation and loss of biodiversity (Bernstein and Cashore 2007). When the 1992 United Nations Conference on Environment and Development (UNCED) failed to produce global reform of forest management, the Forest Stewardship Council (FSC) was created in an attempt to provide more stringent management regulations (Eden and Bear 2010). Similarly, the failure of governments to prevent the collapse of fish stocks in the early 1990s led to the development of MSC in 1997, which was modeled after the FSC (Ponte 2012). Therefore, the origins of FSC and MSC are similar because they were both developed to fill gaps in international policy and considered the nonbinding Earth Summit agreements in the formulation of their standards (Eden and Bear 2010). The MSC is limited to wild caught fisheries and so the World Wildlife Fund also founded the Aquaculture Stewardship Council in 2009, which was inspired by the MSC.

It is recognized that certification scheme standards are in continual review: a new Canadian national FSC standard has been published and will come into effect in 2020 (although the Maritimes standard has not been updated); the MSC standard underwent minor revisions in 2018; and a revised ASC salmon standard will come into effect in December 2019. However, the scope of the three certification schemes have not changed very much or very quickly, and our study provides a time stamp of the similarities and differences at the present time.

Despite the fact that these certification schemes are applied to very different activities, they have a number of similarities. All three are business to consumer certification schemes, which involve labeling systems to influence consumer preferences to bring about changes in management practices (Washington and Ababouch 2011). Each of these schemes also requires third-party certification, whereby a company must hire an external consultant to determine if the company practices meet the certification criteria. These certification schemes used extensive stakeholder involvement and technical consultations during the development of the certification standards. These three certification systems, particularly FSC, are considered to have the most prescriptive 
criteria of similar certification systems, in which particular benchmarks must be met (Gulbrandsen 2009). All of these certification systems use chain of custody standards to ensure the integrity of labeled products.

Most importantly, all of the certification schemes examined have a commitment to the sustainable development concepts developed at the 1992 Earth Summit. We hypothesized that they should therefore have a similar scope of sustainability objectives. This analysis shows, however, that despite common origins and commitments to full spectrum sustainability, certification schemes differ considerably in their scope with only FSC being close to the breadth of the CFRN framework.

\section{Southwest New Brunswick context}

There has been an increase, globally, in considerations of socialecological systems and of the need to move toward ecosystembased management (Long et al. 2015, Smith et al. 2017, Benson and Stephenson 2018). This has been accompanied by increased attention to the relatively neglected social, economic, and institutional pillars of sustainability (e.g., Link et al. 2017, Stephenson et al. 2017), and by the need for full-spectrum sustainability evaluation. Although there may be debate about the classification and hierarchy of these elements, they are all important to the evaluation and management of social-ecological systems (Stephenson et al. 2018).

The southwest New Brunswick area is a good example of the need for the development and application of full-spectrum sustainability for management of diverse activities. The area has to resolve spatial conflicts, as well as conflicting management objectives in overlapping or intersecting activities including fisheries, aquaculture, and forestry. Obvious examples include the need for forest management practices to protect spawning streams of diadromous fish, competition for space and perceived negative interactions between aquaculture and commercial fisheries, and the viability of coastal communities that have traditionally relied on coastal resource-based activities. Conflict among activities led to a decade-long attempt to introduce spatial planning and conflict resolution in the Southwest New Brunswick Marine Resource Planning Initiative, a participatory initiative to improve collaborative and consistent management of marine activities (Parlee and Wiber 2018, Jones and Stephenson 2019). That process, through extensive consultation, came up with a broad set of community values criteria not unlike the full spectrum management objectives laid out in the CFRN framework (Jones and Stephenson 2019).

\section{Full spectrum sustainability in certification?}

The greatest difference among the three certification schemes is their treatment of socioeconomic considerations. The FSC, and to a lesser extent ASC, consider a broad range of socioeconomic elements whereas MSC does not consider any of those identified in the CFRN framework. The lack of social standards within the MSC criteria is not a new discovery or criticism of MSC, however this comparison does highlight the major difference in the scope of objectives of the three certification schemes.

Since its formation, the MSC has struggled with what should be included in its certification. Initially, the MSC considered including five principles, one of which concerned social criteria but the organization eventually dropped this principle (Auld
2012). It is not entirely clear why MSC backed away from social issues though a number of opinions exist. Ponte (2012) suggested that social criteria would have slowed the uptake of certification by complicating the certification process. The MSC was interested in finalizing the criteria and implementing the certification globally as quickly as possible. Social criteria would have added a complicated dimension in the certification process because assessing the compliance of social requirements can be more difficult than environmental standards. Auld (2012) maintained that the environmental issues surrounding wild caught fisheries were already complicated, and the perception that MSC should not try to deal with too many issues led to the exclusion of social criteria. However, there is growing literature emphasizing the importance of full spectrum sustainability in fisheries, and this comparison shows that a global precedent for the inclusion of social criteria in resource harvest certification criteria does exist in FSC and to a lesser extent in ASC. The FSC has the most comprehensive treatment of social and economic objectives in its standards.

The three certification schemes discussed share a common origin and common commitment to sustainable development. In fact, MSC and ASC were formed based on the FSC model. This analysis illustrates that different definitions of sustainable development are being applied across sectors through certifications. Only one falls close to a full spectrum of sustainability as defined by the CFRN framework, and the FSC provides an example of the successful implementation of full spectrum sustainability. To have consistency in management and to achieve sustainability, we emphasize the importance of considering the scope of all management and evaluation schemes being used in an area, including certification schemes. We recommend: (1) use of full spectrum sustainability as articulated in the CFRN framework across activities; and (2) greater attention to consistency in objectives across management and evaluation schemes.

Responses to this article can be read online at: http://www.ecologyandsociety.org/issues/responses. $\mathrm{php} / 11368$

\section{Acknowledgments:}

This research was supported by the Canadian Fisheries Research Network funded by the Natural Sciences and Engineering Research Council of Canada (NET GP 389436-09).

\section{LITERATURE CITED}

Aquaculture Stewardship Council (ASC). 2012. ASC salmon standard: version 1.0 June 2012. Aquaculture Stewardship Council, Utrecht, The Netherlands. [online] URL: http://www. aquameer.com/uploads/5/3/8/3/53830411/asc salmon standard v1.0. pdf

Auld, G. 2012. Emerging private governance: the challenges of choosing a policy focus. Comparative Research in Law and Political Economy 8(9). https://doi.org/10.2139/ssrn.2174016 
Benson, A. J., and R. L. Stephenson. 2018. Options for integrating ecological, economic, and social objectives in evaluation and management of fisheries. Fish and Fisheries 19(1):40-56. https:// doi.org/10.1111/faf.12235

Bernstein, S., and B. Cashore. 2007. Can non-state global governance be legitimate? An analytical framework. Regulation and Governance 1(4):347-371. https://doi.org/10.1111/

j.1748-5991.2007.00021.x

Bush, S. R., B. Belton, D. Hall, P. Vandergeest, F. J. Murray, S. Ponte, P. Oosterveer, M. S. Islam, A. P. J. Mol, M. Hatanaka, F. Kruijssen, T. T. T. Ha1, D. C. Little, and R. Kusumawati. 2013. Certify sustainable aquaculture? Science 341(6150):1067-1068. https://dx.doi.org/10.1126/science. 1237314

Cashore, B. 2002. Legitimacy and the privatization of environmental governance: how non-state market-driven (NSMD) governance systems gain rule-making authority. Governance 15(4)503-529. https://doi.org/10.1111/1468-0491.00199

Clark, M. R., and J. S. Kozar. 2011. Comparing sustainable forest management certifications standards: a meta-analysis. Ecology and Society 16(1):3. https://doi.org/10.5751/ES-03736-160103

Eden, S., and C. Bear. 2010. Third-sector global environmental governance, space and science: comparing fishery and forestry certification. Journal of Environmental Policy and Planning 12 (1):83-106. https://doi.org/10.1080/15239081003626000

Forest Stewardship Council (FSC). 2008. Certification standards for best forestry practices in the Maritimes region. Forest Stewardship Council, Toronto, Ontario, Canada. [online] URL: https://ca.fsc.org/preview.maritimes-standard.a-826.pdf

Gale, F., and M. Haward. 2004. Public accountability in private regulation: contrasting models of the forest stewardship council (FSC) and marine stewardship council (MSC). Australasian Political Studies Association Conference University of Adelaide, Adelaide, Australia.

Government of Canada, Department of Justice (GC DOJ). 1996. Oceans act, revised statutes of Canada. c.31. Government of Canada, Ottawa, Ontario, Canada. [online] URL: http://lawslois.justice.gc.ca/PDF/O-2.4.pdf

Government of Canada, Department of Justice (GC DOJ). 2008. Federal sustainable development act. Revised statutes of Canada. S. C. 2008, c.33. Government of Canada, Ottawa, Ontario, Canada. [online] URL: http://laws-lois.justice.gc.ca/PDF/F-8.6. pdf

Government of New Brunswick (GNB). 2010. New Brunswick finfish aquaculture development strategy 2010-2014. Government of New Brunswick, Fredericton, New Brunswick, Canada. [online] URL: https://www2.gnb.ca/content/dam/gnb/Departments/10/ pdf/Publications/Aqu/FinfishStrategy2010-2014.pdf

Government of New Brunswick (GNB). 2014. Forest management manual for New Brunswick crown lands: results-based forestry option. Government of New Brunswick, Fredericton, New Brunswick, Canada. [online] URL: https://www2.gnb.ca/content/ dam/gnb/Departments/nr-rn/pdf/en/ForestsCrownLands/ $\underline{\text { ScheduleE FMM En.pdf }}$
Gulbrandsen, L. H. 2005. Mark of sustainability? Challenges for fishery and forestry eco-labeling. Environment 47(5):8-23. https:// doi.org/10.3200/ENVT.47.5.8-23

Gulbrandsen, L. H. 2009. The emergence and effectiveness of the marine stewardship council. Marine Policy 33(4):654-660. https:// doi.org/10.1016/j.marpol.2009.01.002

Jacquet, J. L., and D. Pauly. 2007. The rise of seafood awareness campaigns in an era of collapsing fisheries. Marine Policy 31 (3):308-313. https://doi.org/10.1016/j.marpol.2006.09.003

Jonell, M., M. Phillips, P. Rönnbäck, and M. Troell. 2013. Ecocertification of farmed seafood: will it make a difference? Ambio 42(6):659-674. https://doi.org/10.1007/s13280-013-0409-3

Jones, O. P., and R. L. Stephenson. 2019. Practical use of fullspectrum sustainability in the Bay of Fundy. Ecology and Society 24(3):25. https://doi.org/10.5751/ES-11010-240325

Kalfagianni, A., and P. Pattberg. 2013. Fishing in muddy waters: exploring the conditions for effective governance of fisheries and aquaculture. Marine Policy 38:124-132. https://doi.org/10.1016/j. marpol.2012.05.028

Link, J. S., O. Thébaud, D. C. Smith, A. D. M. Smith, J. Schmidt, J. Rice, J. J. Poos, C. Pita, D. Lipton, M. Kraan, S. Frusher, L. Doyen, A. Cudennec, K. Criddle, and D. Bailly. 2017. Keeping humans in the ecosystem. ICES Journal of Marine Science 74 (7):1947-1956. https://doi.org/10.1093/icesjms/fsx130

Long, R. D., A. Charles, and R. L. Stephenson. 2015. Key principles of marine ecosystem-based management. Marine Policy 57:53-60. https://doi.org/10.1016/j.marpol.2015.01.013

Marine Stewardship Council (MSC). 2014. MSC fisheries standard and guidance Version 2.0. Marine Stewardship Council, London, UK. [online] URL: https://www.msc.org/docs/defaultsource/default-document-library/for-business/program-documents/ fisheries-program-documents/fisheries standard_v2-0.pdf

Marine Stewardship Council (MSC). 2019b. Track a fishery - Bay of Fundy, Scotian Shelf and southern Gulf of St. Lawrence lobster trap. Marine Stewardship Council, London, UK. [online] URL: https://fisheries.msc.org/en/fisheries/bay-of-fundy-scotian-shelf-andsouthern-gulf-of-st.-lawrence-lobster-trap/@@,view

Marine Stewardship Council (MSC). 2019c. Track a fishery Canadian 4VWX purse seine herring fishery. Marine Stewardship Council, London, UK. [online] URL: https://fisheries.msc.org/ en/fisheries/canadian-4vwx-purse-seine-herring-fishery/@,@view

Marine Stewardship Council (MSC). 2019a. Track a fishery FBSA Canada full bay sea scallop. Marine Stewardship Council, London, UK. [online] URL: https://fisheries.msc.org/en/ fisheries/fbsa-canada-full-bay-sea-scallop/@@view

Parkes, G., J. A. Young, S. F. Walmsley, R. Abel, J. Harman, P. Horvat, A. Lem, A. MacFarlane, M. Mens, and C. Nolan. 2010. Behind the signs-a global review of fish sustainability information schemes. Reviews in Fisheries Science 18(4):344-356. https://doi. org/10.1080/10641262.2010.516374

Parlee, C. E., and M. G. Wiber. 2018. Using conflict over risk management in the marine environment to strengthen measures 
of governance. Ecology and Society 23(4):5. https://doi. org/10.5751/ES-10334-230405

Pikitch, E. K., C. Santora, E. A. Babcock, A. Bakun, R. Bonfil, D. O. Conover, P. Dayton, P. Doukakis, D. Fluharty, B. Heneman, E. D. Houde, J. Link, P. A. Livingston, M. Mangel, M. K. McAllister, J. Pope, and K. J. Sainsbury. 2004. Ecosystem-based fishery management. Science 305(5682):346-347. https://doi. org/10.1126/science. 1098222

Ponte, S. 2012. The marine stewardship council (MSC) and the making of a market for 'sustainable fish'. Journal of Agrarian Change 12(23):300-315. https://doi.org/10.1111/j.1471-0366.2011.00345. $\underline{\mathrm{X}}$

Rametsteiner, E., and M. Simula. 2003. Forest certification: an instrument to promote sustainable forest management? Journal of Environmental Management 67(1):87-98. https://doi. org/10.1016/s0301-4797(02)00191-3

Schlyter, P., I. Stjernquist, and K. Bäckstrand. 2009. Not seeing the forest for the trees? The environmental effectiveness of forest certification in Sweden. Forest Policy and Economics 11:375-382. https://doi.org/10.1016/j.forpol.2008.11.005

Smith, D. C., E. A. Fulton, P. Apfel, I. D. Cresswell, B. M. Gillanders, M. Haward, K. G. Sainsbury, A. D. M. Smith, J. Vince, and T. M. Ward. 2017. Implementing marine ecosystem-based management: lessons from Australia. ICES Journal Marine Science 74(7):1990-2003. https://doi.org/10.1093/icesjms/fsx113

Stephenson, R. L., A. J. Benson, K. Brooks, A. Charles, P. Degnbol, C. M. Dichmont, M. Kraan, S. Pascoe, S. D. Paul, A. Rindorf, and M. Wiber. 2017. Practical steps toward integrating economic, social and institutional elements in fisheries policy and management. ICES Journal of Marine Science 74(7):1981-1989. https://doi.org/10.1093/icesjms/fsx057

Stephenson, R. L., A. J. Hobday, C. Cvitanovic, K. A. Alexander, G. A. Begg, R. Bustamante, P. K. Dunstan, S. Frusher, M. Fudge, E. A. Fulton, M. Haward, C. Macleod, J. McDonald, K. L. Nash, E. Ogier, G. Pecl, É. E. Plagányi, I. van Putten, T. Smith, and T. M. Ward. 2019a. A practical framework for implementing and evaluating integrated management of marine activities. Ocean and Coastal Management 177:127-138. https://doi.org/10.1016/j. ocecoaman.2019.04.008

Stephenson, R. L., S. Paul, M. Wiber, E. Angel, A. Benson, A. Charles, O. Chouinard, M. Clemens, D. Edwards, P. Foley, L. Jennings, O. Jones, D. Lane, J. McIsaac, C. Mussells, B. Neis, B. Nordstrom, C. Parlee, E. Pinkerton, M. Saunders, K. Squires, and U. R. Sumaila. 2018. Evaluating and implementing socialecological systems: a comprehensive approach to sustainable fisheries. Fish and Fisheries 19(5):853-873. https://doi. org/10.1111/faf.12296

Stephenson, R. L., M. Wiber, S. Paul, E. Angel, A. Benson, A. Charles, O. Chouinard, D. Edwards, P. Foley, D. Lane, J. McIsaac, B. Neis, C. Parlee, E. Pinkerton, M. Saunders, K. Squires, and R. U. Sumaila. 2019b. Integrating diverse objectives for sustainable fisheries in Canada. Canadian Journal of Fisheries and Aquatic Sciences 76:480-496. https://doi.org/10.1139/cjfas-2017-0345
Thompson, S., R. L. Stephenson, G. A. Rose, and S. D. Paul. 2019. Reshaping fisheries research in Canada: the Canadian Fisheries Research Network. Canadian Journal of Fisheries and Aquatic Sciences 76:671-681. https://doi.org/10.1139/cjfas-2018-0450

Tikina, A. V., and J. L. Innes. 2008. A framework for assessing the effectiveness of forest certification. Canadian Journal of Forest Research 3(86):1357-1365. https://doi.org/10.1139/X08-011

Washington, S., and L. Ababouch. 2011. Private standards and certification in fisheries and aquaculture: current practice and emerging issues. FAO Fisheries and Aquaculture Technical Paper No. 553. FAO, Rome, Italy. [online] URL: http://www.fao.org/3/ i1948e/i1948e.pdf 
Appendix 1: Detailed comparison of the Canadian Fisheries Research Network framework for comprehensive evaluation of fisheries sustainability (presented in Stephenson et al. 2019b) with the scope of three certifications schemes: Forest Stewardship Council, Aquaculture Stewardship Council and Marine Stewardship Council in Southwest New Brunswick.

\begin{tabular}{|c|c|c|c|}
\hline $\begin{array}{l}\text { CFRN Framework } \\
1.1\end{array}$ & Forest Stewardship Council & Aquaculture Stewardship Council & Marine Stewardship Council \\
\hline 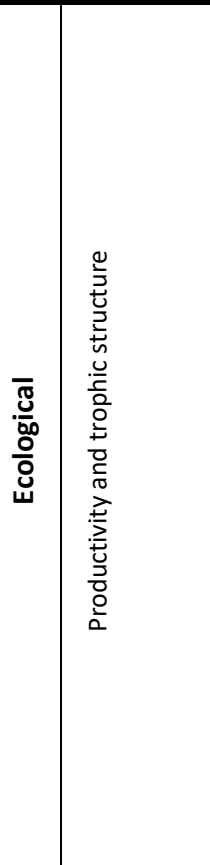 & $\begin{array}{l}\text { 6.3 Ecological functions and values shall be maintained intact, enhanced and } \\
\text { restored, including :a) forest regeneration and succession; and c) natural cycles } \\
\text { that affect the productivity of the forest ecosystem } \\
6.9 \text { The use of exotic species shell be carefully controlled and actively monitored } \\
\text { to avoid adverse ecological impacts } \\
6.10 \text { Forest conversion to plantations or non-forest land uses shall not occur, } \\
\text { except in circumstances where conversion: } \text { c) will enable clear, sustainable, } \\
\text { additional, secure long-term conservation benefits across the forest management } \\
\text { unit }\end{array}$ & $\begin{array}{l}\text { 2.5 Conserve natural habitat, local biodiversity and ecosystem function: } \\
\text { Interaction with wildlife including predators } \\
3.1 \text { Protect the health and genetic integrity of wild population: Introduced or } \\
\text { amplified parasites and pathogens } \\
\text { 3.2 Protect the health and genetic integrity of wild population: Introduction of } \\
\text { non-native species } \\
4.1 \text { Use resources in an environmentally efficient and responsible manner: } \\
\text { Traceability of raw materials in feed } \\
4.2 \text { Use resources in an environmentally efficient and responsible manner: Use of } \\
\text { wild fish for feed } \\
4.3 \text { Use resources in an environmentally efficient and responsible manner: Source } \\
\text { of marine raw materials } \\
4.4 \text { Use resources in an environmentally efficient and responsible manner: Source } \\
\text { of non-raw materials in feed }\end{array}$ & $\begin{array}{l}\text { 1.1.1 The stock is at a level which maintains high productivity and has a low } \\
\text { probability of recruitment overfishing } \\
\text { 1.1.2 Where the stock is reduced, there is evidence of stock rebuilding within a } \\
\text { specified timeframe. } \\
\text { 1.2.1 There is a robust and precautionary harvest strategy in place } \\
\text { 2.1.1 The UoA aims to maintain primary species above the point where } \\
\text { recruitment would be impaired (PRI) and does not hinder recovery of primary } \\
\text { species if they are below the PRI. } \\
\text { 2.1.2 There is a strategy in place that is designed to maintain or to not hinder } \\
\text { rebuilding of primary species; and the UoA regularly reviews and implements } \\
\text { measures, as appropriate, to minimise the mortality of unwanted catch. } \\
\text { 2.2.1 The UoA aims to maintain secondary species above a biologically based limit } \\
\text { and does not hinder recovery of secondary species if they are below a biologically } \\
\text { based limit. } \\
\text { 2.2.2 There is a strategy in place for managing secondary species that is designed } \\
\text { to maintain or to not hinder rebuilding of secondary species; and the UoA } \\
\text { regularly reviews and implements measures, as appropriate, to minimise the } \\
\text { mortality of unwanted catch. } \\
\text { 2.5.1 The UoA does not cause serious or irreversible harm to the key elements of } \\
\text { ecosystem structure and function. } \\
\text { 2.5.2 There are measures in place to ensure the Unit of Assessment does not pose } \\
\text { a risk of serious or irreversible harm to ecosystem structure and function. }\end{array}$ \\
\hline
\end{tabular}




\begin{tabular}{|c|c|c|c|c|}
\hline & 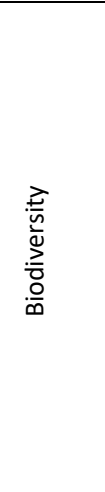 & $\begin{array}{l}\text { 6.2 Safeguards shall exists which protect rare, threatened and endangered species } \\
\text { and their habitats (e.g. nesting and feeding areas). Conservation zones and } \\
\text { protection areas shall be established, appropriate to the scale and intensity of } \\
\text { forest management and the uniqueness of the affected resources. Inappropriate } \\
\text { hunting, fishing, trapping and collecting shall be controlled. } \\
6.3 \text { Ecological functions and values shall be maintained intact, enhances and } \\
\text { restored, including : b) genetic, species and ecosystem diversity } \\
6.4 \text { Representative samples of existing ecosystems within the landscape shall be } \\
\text { protected in their natural state and recorded on maps, appropriate to the scale } \\
\text { and intensity of operations and the uniqueness of the affected resources } \\
6.10 \text { Forest conversion to plantations or non-forest land uses shall not occur, } \\
\text { except in circumstances where conversion: a) entails a very limited portion of the } \\
\text { forest management unit }\end{array}$ & $\begin{array}{l}\text { 2.1 Conserve natural habitat, local biodiversity and ecosystem function: benthic } \\
\text { biodiversity and benthic effects } \\
\text { 2.4 Conserve natural habitat, local biodiversity and ecosystem function: } \\
\text { Interaction with critical or sensitive habitats and species } \\
\text { 3.3 Protect the health and genetic integrity of wild population: Introduction of } \\
\text { transgenic species } \\
3.4 \text { Protect the health and genetic integrity of wild population: Escapes }\end{array}$ & $\begin{array}{l}\text { 2.3.2 The UoA has in place precautionary management strategies designed to: - } \\
\text { meet national and international requirements; and - ensure the UoA does not } \\
\text { hinder recovery of ETP species. Also, the UoA regularly reviews and implements } \\
\text { measures, as appropriate, to minimise the mortality of ETP species. }\end{array}$ \\
\hline & 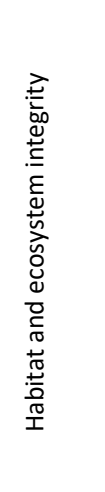 & $\begin{array}{l}\text { 6.5 Written guidelines shall be prepared and implemented to control erosion; } \\
\text { minimize forest damage during harvesting, road construction and all other } \\
\text { mechanical disturbances; and protect water resources } \\
6.6 \text { Management systems shall promote the development and adoption of } \\
\text { environmentally friendly non-chemical methods of pest management and strive } \\
\text { to avoid the use of chemical pesticides [...] } \\
6.7 \text { Chemical, containers, liquid and solid non-organic wastes including fuel and oil } \\
\text { shall be disposed of in an environmentally appropriate manner at off-site } \\
\text { locations } \\
6.10 \text { Forest conversion to plantations or non-forest land uses shall not occur, } \\
\text { except in circumstances where conversion: b) does not occur on high } \\
\text { conservation value forest land }\end{array}$ & $\begin{array}{l}2.2 \text { Conserve natural habitat, local biodiversity and ecosystem function: Water } \\
\text { quality in and near the site of operation } \\
2.3 \text { Conserve natural habitat, local biodiversity and ecosystem function: Nutrient } \\
\text { release from production } \\
2.4 \text { Conserve natural habitat, local biodiversity and ecosystem function: } \\
\text { Interaction with critical or sensitive habitats and species } \\
4.5 \text { Use resources in an environmentally efficient and responsible manner: Non- } \\
\text { biological waste from production } \\
4.6 \text { Use resources in an environmentally efficient and responsible manner: Energy } \\
\text { consumption and greenhouse gas emissions on farms } \\
4.7 \text { Use resources in an environmentally efficient and responsible manner: Non- } \\
\text { therapeutic chemical inputs }\end{array}$ & $\begin{array}{l}\text { 2.4.1 The UoA does not cause serious or irreversible harm to habitat structure and } \\
\text { function, considered on the basis of the area covered by the governance body(s) } \\
\text { responsible for fisheries management in the area(s) where the UoA operates. } \\
\text { 2.4.2 There is a strategy in place that is designed to ensure the UoA does not pose } \\
\text { a risk of serious or irreversible harm to the habitats. }\end{array}$ \\
\hline 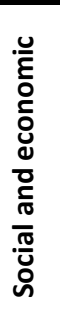 & 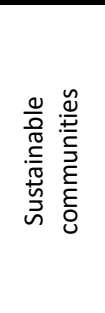 & $\begin{array}{l}\text { 4.1 The communities within, or adjacent to, the forest management area should } \\
\text { be given opportunities for employment, training and other services } \\
\text { 4.4 Management and planning operations shall incorporate the results of } \\
\text { evaluations of social impact. Consultations shall be maintained with people and } \\
\text { groups (both men and women) directly affected by management operations } \\
5.5 \text { Forest management operations shall recognize, maintain and, where } \\
\text { appropriate, enhance the forest services and resources such as watersheds and } \\
\text { fisheries }\end{array}$ & & \\
\hline
\end{tabular}




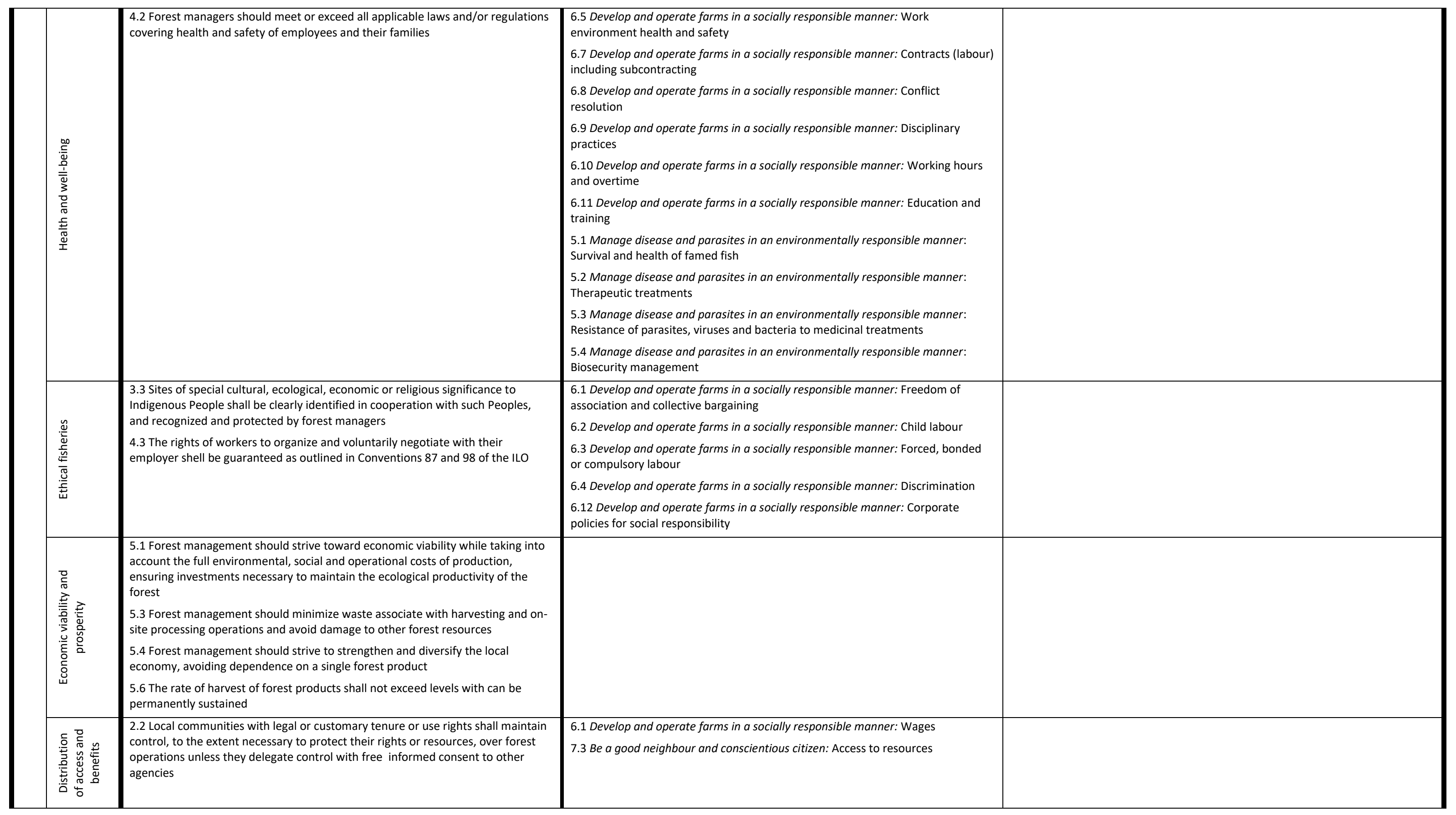




\begin{tabular}{|c|c|c|c|c|}
\hline & 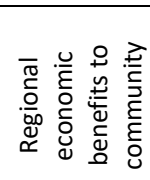 & $\begin{array}{l}5.2 \text { Forest management and marketing operations should encourage the optimal } \\
\text { use and local processing of the forest's diversity of products }\end{array}$ & & \\
\hline 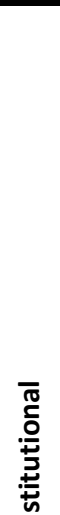 & 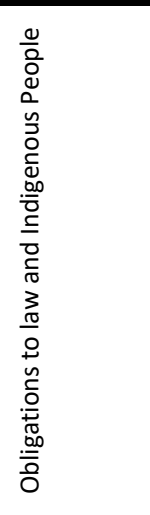 & $\begin{array}{l}\text { 1.3 In signatory countries, the provisions of all binding international agreements } \\
\text { such as CITES, ILO Conventions, ITTA, and Convention on Biological Diversity, shall } \\
\text { be respected } \\
\text { 1.4 Conflicts between laws, regulations and the FSC Principles and Criteria shall be } \\
\text { evaluated for the purposes of certification, on a case by case basis, by the } \\
\text { certifiers and the involved or affected parties } \\
2.1 \text { Clear evidence of long term forest use rights to the land (e.g. land title, } \\
\text { customary rights, or lease agreements) shall be demonstrated } \\
2.3 \text { Appropriate mechanisms shall be employed to resolve disputes over tenure } \\
\text { claims and use rights. The circumstances and status of any outstanding disputes } \\
\text { will be explicitly considered } \\
\text { 3.2 Forest management shall not threaten or diminish, either directly or indirectly, } \\
\text { the resources or tenure rights of indigenous people }\end{array}$ & $\begin{array}{l}7.2 \text { Be a good neighbour and conscientious citizen: respect for indigenous } \\
\text { aboriginal cultures and traditional territories }\end{array}$ & $\begin{array}{l}\text { 3.1.1 The management system exists within an appropriate and effective legal } \\
\text { and/or customary framework which ensures that it: - Is capable of delivering } \\
\text { sustainability in the Unit of Assessment(s) - Observes the legal rights created } \\
\text { explicitly or established by custom of people dependent on fishing for food or } \\
\text { livelihood; and -Incorporates an appropriate dispute resolution framework. }\end{array}$ \\
\hline & 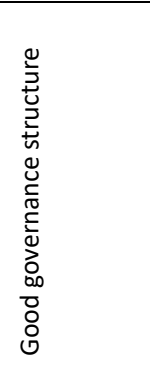 & $\begin{array}{l}\text { 1.1 The operation complies with all [applicable] legislation } \\
\text { 1.5 Forest management areas should be protected from illegal harvesting, } \\
\text { settlement and other unauthorized activities } \\
3.1 \text { Indigenous people shall control forest management on their lands and } \\
\text { territories unless they delegate control with free and informed consent to other } \\
\text { agencies } \\
6.8 \text { Use of biological control agents shall be documented, minimized, monitored, } \\
\text { and strictly controlled in accordance with national laws and internationally } \\
\text { accepted scientific protocols. Use of genetically modified organisms shall be } \\
\text { prohibited }\end{array}$ & $\begin{array}{l}1.1 \text { Compliance with all applicable local and national legal requirements and } \\
\text { regulations }\end{array}$ & $\begin{array}{l}\text { 2.3.1 The UoA meets national and international requirements for protection of } \\
\text { ETP species. The UoA does not hinder recovery of ETP species. }\end{array}$ \\
\hline
\end{tabular}




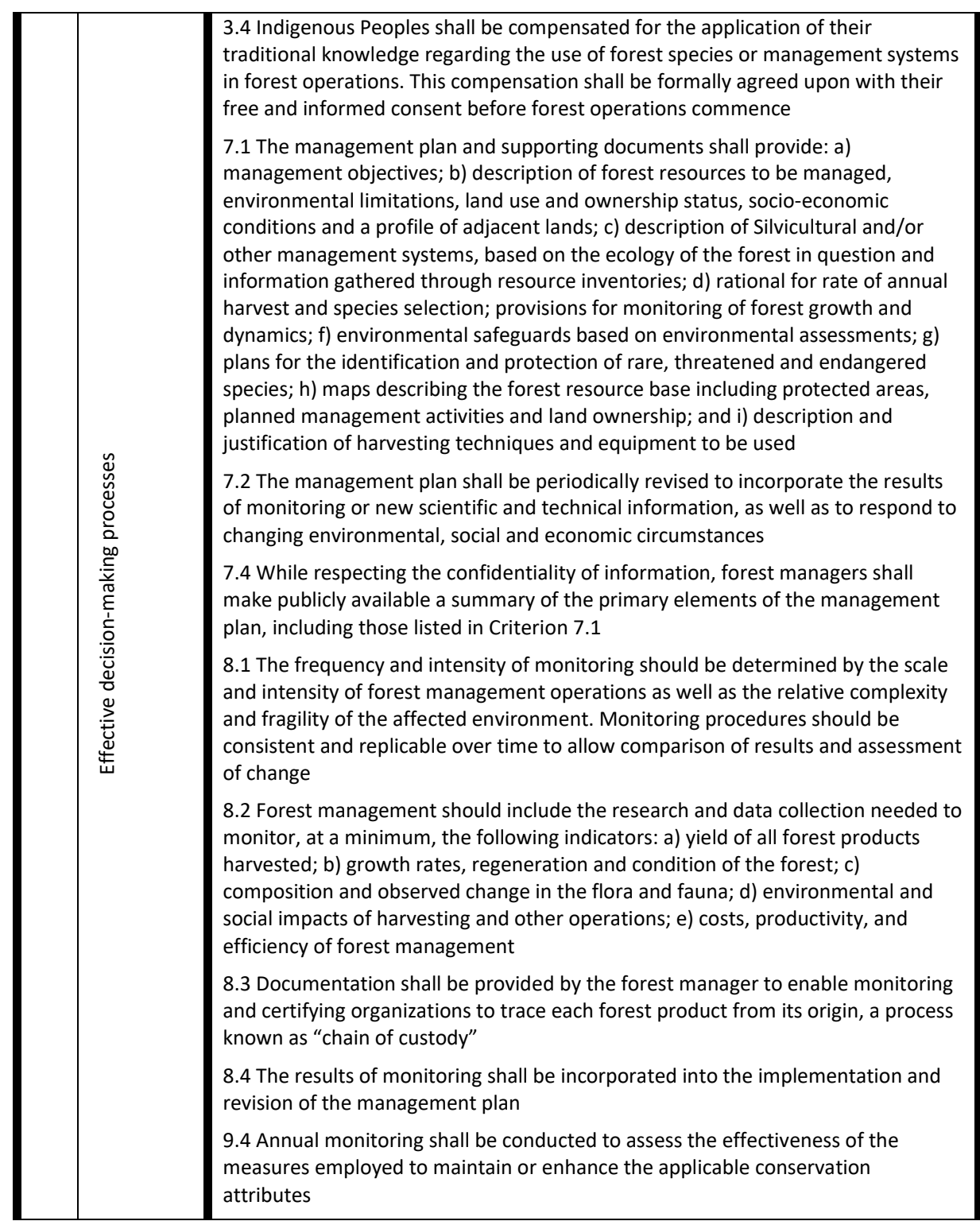

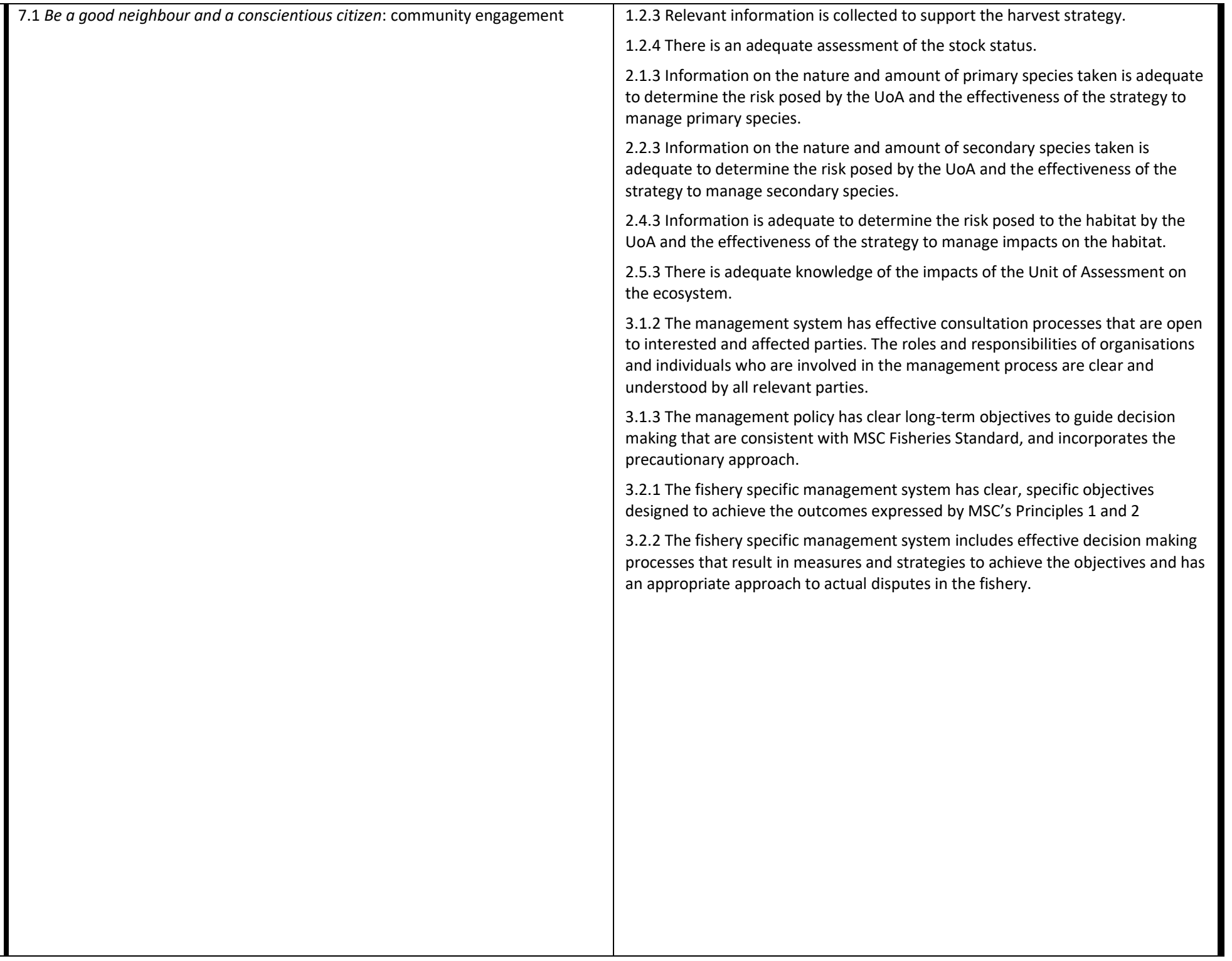

